\title{
ПСИХОЛОГО-ПЕДАГОГІЧНІ АСПЕКТИ ПІДГОТОВКИ МАЙБУТНІХ УЧИТЕЛІВ ПОЧАТКОВОЇ ШКОЛИ ДО ОРГАНІЗАЦЇ̈ ГРУПОВИХ ФОРМ ПІЗНАВАЛЬНОЇ ДІЯЛЬНОСТІ
}

Дуднік А. О. Психолого-педагогічні аспекти підготовки майбутніх учителів початкової школи до організації групових форм пізнавальної діяльності.

У статті розглянуто психолого-педагогічні аспекти підготовки майбутніх учителів початкової школи до організації групових форм пізнавальної діяльності, визначено сутність поняття «форма організації навчання», окреслено вимоги щодо підвищення ефективності групової діяльності учнів, охарактеризовано професійні якості педагога, що забезпечують успішність навчально-виховного процесу.

Ключові слова: підготовка майбутніх учителів, групові форми навчання, педагогічні умови, професійні якості педагога.

Дудник А. А. Психолого-педагогические аспекты подготовки будущих учителей начальной школы к организации групповых форм познавательной деятельности.

В статье рассмотрены психолого-педагогические аспекты подготовки будущих учителей начальной школы к организации групповых форм познавательной деятельности, определена суть понятия «форма организации обучения», очерчены требования к повышению эффективности групповой деятельности учащихся, охарактеризованы профессиональные качества педагога, которые обеспечивают успешность учебно-воспитательного процесса.

Ключевые слова: подготовка будущих учителей, групповые формы обучения, педагогические условия, профессиональные качества педагога.

Dudnik A. O. Psychologial-and-pedagogial aspects of primary schools future teachers' training for the group froms' organization of cognitive activity.

Psychologial-and-pedagogial aspects of primary schools future teachers' training for the group froms' organization of cognitive activity have been considered; the notion «organization from of learning» has been determined; requisitions as for the raising or the effectiveness of pupils' group activity have been outlined; teachers' professional qualities that provide the effectiveness of educational-and-training process have been described in the article.

Key words: future teachers' training, group froms of learning, pedagogical conditions, teachers' professional qualities.

Готовність майбутнього вчителя початкової школи до організації групової форми навчання учнів грунтується на психологічній, педагогічній і предметній підготовці, що передбачає насамперед сформованість особистих якостей педагога. Сучасна педагогічна наука акцентує на нагальній проблемі підготовки педагогів, спроможних до швидкої адаптації в умовах постійної інформаційної навантаженості в системі соціальних знань. Цьому питанню присвятили теоретичні праці такі видатні науковці: А. Алексюк, А. Богуш, В. Бондар, М. Євтух, Т. Ільїна, Л. Кондрашова, Н. Кузьмін, А. Кузьмінський, М. Нікандров, Н. Ничкало, О. Пєхота, О. Плахотник, О. Пометун, О. Савченко, В. Сластьонін, Б. Федоришин, Р. Хмелюк, О. Щербаков та інші. Аналіз вітчизняної та зарубіжної психолого-педагогічної літератури засвідчує, що відбір і структурування змісту середньої і вищої освіти - одна з найскладніших, визначальних проблем у контексті якості освіти відповідно до вимог часу [2, с. 2].

Meта статmi - розглянути психолого-педагогічні аспекти підготовки майбутніх учителів початкової школи до організації групових форм пізнавальної діяльності.

У дидактичній літературі частовживаними є такі терміни: форми навчання, організаційні форми навчання, форми організації навчальної діяльності. Відомий педагог Т. Ільїна вважає, що коли йдеться про класно-урочну систему навчання, про урок й інші навчальні заняття (екскурсії, семінари), індивідуальне та колективне навчання, вживається поняття «форми організації навчання». Ії позиція полягає в розумінні сутності цього поняття: «Під формою організації навчання слід розуміти спеціально організовану діяльність учителя й учнів, яка протікає в установленому порядку й у визначеному режимі» [4, с. 347]. Дослідниця вживає також і термін «організаційна форма». 
Термін «форма організації навчання» має різні тлумачення. Зокрема, у практиці вищої школи це поняття визначається як засіб організації, облаштування і проведення навчальних занять, у межах яких реалізуються зміст навчальної роботи, дидактичні завдання й методи навчання. До форм організації навчання зазвичай відносять: лекції, семінарські, лабораторні заняття, колоквіуми, консультації, екскурсії, курсові та дипломні роботи, заліки, екзамени тощо [5, с. 246].

Однією з причин цього $\epsilon$ наявність різних тлумачень понять «форма організації навчання» (способів організації процесу навчання) й «форма навчальної діяльності учнів» (колективного або індивідуального характеру взаємодії між школярами у процесі навчання). Зокрема, колективну й індивідуальну форму навчальної діяльності учнів можна реалізувати по-різному: колективну - в умовах групової або фронтальної роботи.

Групова форма навчання дає змогу давати основи грамоти чималій кількості дітей порівняно 3 індивідуальною формою. Сутність форм організації навчання зводиться до зовнішнього вираження діяльності вчителя й учнів, що здійснюється у встановленому порядку та певному режимі. У груповій роботі учнів можна використовувати колективну й індивідуальну форми навчальної діяльності. Перша форма роботи передбачає лише спільні зусилля учнів груп виконати поставлені завдання - спільне планування; друга - організацію групової роботи школярів із переважанням індивідуальної діяльності (після розподілу доручень кожен учень виконує свою частину навчального завдання самостійно). Але співпраця в групах на може складатися з індивідуальної роботи, а неодмінно має містити певну частину колективної - розподіл доручень, взаємоперевірку, взаємооцінювання тощо.

Форми організації навчання за ознакою місця їх проведення поділяються на три групи:

- заняття, що проводяться в школі - урок, факультатив, семінар, практичні та лабораторні заняття, заняття в навчальних майстернях, співбесіда, консультація, екзамен тощо;

- заняття, що проводяться поза школою - екскурсії, олімпіади, конкурси, гуртки, студії, клуби, станції в позашкільних навчально-виховних закладах тощо;

- заняття вдома - виконання домашніх завдань (самопідготовка).

На будь-якому навчальному занятті, яке стосується форм організації процесу навчання, учитель організовує пізнавальну діяльність учнів різного ступеня залучення їх до процесу спілкування. Зовнішнім виявленням взаємодії суб'єктів навчального процесу $є$ форми організації навчальної діяльності учнів: індивідуальна, парна, групова, загальнокласна, фронтальна та їх різноманітні поєднання.

Щодо поняття «форма навчання», слід мати на увазі такі ознаки, як рівень самостійності суб'єктів навчання під час виконання ними навчального плану та програм і використання контролю результатів. Ці ознаки по-різному виявляються в таких формах навчання: стаціонарна (денна), вечірня, заочна, очно-заочна, екстернатна, дистанційна (за допомогою листування, комп'ютерних мереж, кабельного та супутникового телебачення), домашня освіта 3 обов'язковою державною атестацією (для інвалідів).

Різноманітні дидактичні поняття, що стосуються формальних ознак часу, місця, стилю спілкування, можна віднести до однієї 3 трьох педагогічних категорій: форма організації навчання, форма організації навчальної діяльності та форма навчання або освіти [1, с. 123].

Щодо інших широковживаних форм навчальної діяльності (індивідуальної, фронтальної, загальнокласної), групова навчальна діяльність $є$ найбільш коректною, етичною, рефлексивною, саморегулятивною. Учитель переводить учнів зі стану прямого педагогічного керування в саморегулятивну ситуацію, тобто в стан, за якого формуються і використовуються спеціальні вміння й навички, зокрема: правильно сприймати вимоги, які ставлять перед учнями вчителі; правильно оцінювати свої навчальні можливості та визначити індивідуальну міру допомоги з боку вчителя чи інших учнів; ставити вимоги перед собою, пов'язувати їх зі своїми потребами і задовольняти їх; уміти долати побічні бажання, які заважають навчальній діяльності, абстрагуватися й включатися в активну посильну діяльність; у випадку виникнення утруднень аналізувати їх, знаходити правильні рішення чи звертатися за допомогою.

Групове навчання як специфічна форма його організації спочатку зародилася в 20 -ті роки XX ст. в царині Дальтон-плану (США), а в 50-60-х роках - розвивалася в умовах гострої критики фронтальної роботи учнів. Педагоги та психологи європейських країн, доповнюючи навчальну діяльність новими ознаками (повною свободою, самостійністю учнів при посиленні їхньої взаємодії в навчанні), аж до повного відходу від класно-урочної системи («відкрите навчання»), 
теоретично й практично обгрунтували сутність групової диференціації навчання. На відміну від простого зібрання людей, ознаками групи вони вважають: тривалість взаємодії; наявність спільних ідеалів, уявлень і звичок; активна участь кожного в життєдіяльності групи; наявність спільної мети; початкова поява потреби в спілкуванні й задоволення від діяльності.

Науковцями досліджено питання про численність членів групи і доведено, що за межами кількості членів групи в 6-7 осіб ступінь згуртованості починає слабшати в силу ускладнення спілкування, що значно знижує ефективність навчання. Найбільш оптимальною $є$ численність малої групи як одиниці групової навчальної діяльності 3 4-5 осіб. Дослідники дійшли висновку, що створення малих груп має здійснюватися не за однорідними, а за змішаними здібностями до навчання. Однорідний за здібностями склад малих груп не впливає на підвищення успішності навчання. У змішаних групах менше залишається нерозв'язаних завдань, активність і самостійність розвивається і в слабких, і в середніх, і в сильних за навчальними можливостями учнів [1, с. 125].

Для підвищення ефективності групової діяльності учнів слід дотримуватися таких вимог:

- усі члени малих груп самостійно розв'язують поставлену перед класом проблему;

- кожний учасник групи обгрунтовує свою альтернативу розв'язку без обговорення й оцінювання (чим усувається проблема лідерства);

- кожен член групи вибирає найкращий, на його думку, варіант розв'язку, а педагогічне рішення приймає клас разом з учителем.

За неправильного керівництва діяльністю груп не виключено, що поставлені перед ними завдання можуть виконуватися найбільш здібними учнями. Групове розв'язання може бути нераціональним за рахунок думки меншості, тобто сильних учнів без участі членів групи 3 середніми та слабкими навчальними можливостями. Групова діяльність потребує більше часу, ніж індивідуальна робота [1, с. 126].

Особливої значущості набуває в умовах кардинальних змін у науково-технічній, соціальноекономічній і освітньо-педагогічній сферах проблема підготовки майбутнього учителя до організації групових форм роботи навчання. В основу відбору і конструювання змісту середньої загальної освіти покладено переважно соціокультурний підхід, сутність якого полягає в необхідності відображати в освіті основні елементи соціокультурного досвіду. Культура як система знань, умінь, відповідних поглядів і переконань, творчості та ціннісних орієнтацій складає основу загальної освіти, якою має володіти вчитель, щоб соціокультурний досвід передавати дітям. Але це один, предметно-змістовий аспект професійної підготовки вчителя. Інший - оволодіння майбутнім фахівцем сучасним досвідом психолого-педагогічного знання про об'єкт освіти та способи організації, здійснення й оцінювання результатів професійної діяльності. По-друге, оволодіння системою загальних, міжциклових і фахово-інтегрованих умінь і навичок, наявність яких забезпечує ефективність багатофункціональної професійної діяльності вчителя; вироблення здатності творчо застосувати сучасні наукові досягнення в галузі педагогіки, психології, методики, технології у практичній навчально-виховній роботі та вмінь проектувати нові й використовувати відомі технології навчання, виховання й розвитку особистості школярів. По-третє, присвоєння досвіду ціннісного ставлення до предмета професійної діяльності, так необхідного для гуманного надання йому освітніх послуг, задоволення його потреб в освіті, забезпечення вдоволеності батьків від результатів роботи з їхніми дітьми [2, с. 2].

Освіта має сприяти формуванню самостійного мислення вчителя, упровадження індивідуального підходу до розвитку його творчих здібностей, докорінному поліпшенню оволодіння професійними навичками. Від цього залежить, якою мірою конкурентоспроможні педагоги зможуть поєднувати сучасні знання, професіоналізм із соціальною активністю і високою моральністю. Конкурентоспроможний учитель має володіти комплексом моральноестетичних якостей: гуманізмом, високою культурою, ввічливістю, чесністю, вимогливістю.

Вольові якості мають велике значення для успішної професійної діяльності педагога, до яких належать витримка (володіння собою), наполегливість, терпимість, вимогливість, рішучість, сміливість. Інтелектуальні якості вчителя зумовлюють його професійні вміння, допомагають приймати правильні рішення, сприяють творчості, пошуку нових, неординарних шляхів розв'язання проблем. Серед цих якостей - чіткість і логіка мислення, його критичність, творча уява, винахідливість, дотепність. Особливу роль у професійній діяльності відіграє оперативність мислення, що характеризує здатність педагога швидко знаходити оптимальні 
розв'язання професійних завдань. Інтелектуальні якості грунтуються на перцептивних й атенційних якостях, що впливають на сприйняття й увагу. Професійні здібності - це сукупність достатньо стійких індивідуально психологічних якостей і властивостей особистості, що визначають успішність професійного навчання або діяльності з певного фаху.

Формування і розвиток творчої особистості вчителя на основі підтримки педагогічного колективу, прагнення, аби знання як самоціль поступилися місцем знанням як інструментові життя, - провідна мета діяльності сучасної школи. Необхідно визначити зміст професійної компетентності. Поняття компетентності, за визначенням I. Срмакова, - це здатність людини ефективно розв'зувати проблеми, що виникають у реальних життєвих ситуаціях, діяти адекватно вимогам соціуму й у відповідності з власною природою.

Оцінювати компетентність пропонують за такими показниками: знання, вміння, навички, навчальні досягнення. Т. Браже розглядає професійну компетентність як багатофакторне утворення, що уможливлює успішне здійснення професійної діяльності [3, с. 5].

Педагогічна майстерність і творчість учителя виявляється в умінні передбачити труднощі і прогнозувати результати, здійснювати організаційні заходи замість дисциплінарних, оперативно знаходити оптимальне педагогічне рішення у нестандартних ситуаціях. А навчально-виховний процес має постати складником загального процесу соціалізації особистості, де цілеспрямовано формуються вихованість, професійні якості ділової людини. У сучасних умовах конкурентоспроможність набуває дедалі більшого значення не тільки для особистості, а й для суспільства загалом, оскільки є стратегічною у процесі його розвитку. Вона затребувана нині й у майбутньому, на що вказують тенденції розвитку сучасної освіти.

Педагог початкової школи зобов'язаний організувати роботу з класом і систематично залучати учнів до пошуку засобів забезпечення їх максимальної самореалізації інтелектуального та творчого потенціалу без збільшення емоційного напруження для інших. У процесі навчальної діяльності, як свідчать дані досліджень, творчі педагоги частіше наголошують на позитивних рисах учнів, що забезпечує виявлення творчого потенціалу через їх стійкість у досягненні результату, їх працелюбність, організованість поведінки та почуття честі.

Навчальна діяльність потребує від учня бути долученим до розв'язання загальних завдань, які дає педагог на уроці, а також до групового спілкування, діалогу з класом. У масштабах групового спілкування засвоєння знань відбувається в учнів більш успішно. У цьому процесі індивідуальні зусилля кожної особистості об'єднуються і за правильного керівництва педагога швидше і точніше спрямовуються на розв'язання навчального завдання, що в результаті дає «груповий ефект». Дієвим засобом формування вміння вчитися, створення оптимальних умов для розвитку особистості $\epsilon$ навчальна діяльність учнів у групах, за якої кожен учасник робить унікальний внесок у спільну навчальну діяльність, а його зусилля потрібні й незамінні для загального успіху.

Отже, зроблені спостереження дозволяють стверджувати, що проблема підготовки майбутніх учителів початкової школи до організації групових форм пізнавальної діяльності повною мірою не розв'язана. Використання ж групових форм пізнавальної діяльності у практиці початкової школи потребує від майбутніх учителів готовності до її організації та реалізації в навчально-виховному процесі початкової ланки освіти.

\section{Література}

1. Боднар В. І. Дидактика / Володимир Іванович Бондар. - К. : Либідь, 2005. - 264 с. 2. Боднар В. Філософія стандартизації змісту професійної освіти вчителя початкової школи в умовах двоциклової підготовки у ВНЗ / В. Бондар // Початкова школа. - 2012. - № 12. - С. 2-3. 3. Завалевський Ю. Становлення конкурентноспроможного педагога в сучасному навчальному закладі / Юрій Завалевський // Початкова школа. - 2012. - №12 - С. 4-6. 4. Ильина Т. А. Педагогика / Т. Ильина. - М. : Просвещение, 1998. - 570 с. 5. Кузьмінський А. І. Педагогіка вищої школи : [навч. посіб.] / А. І. Кузьмінський. - К. : Знання, 2005. - 486 с. 6. Лийметс Х. Й. Групповая работа на уроке / Х. Й. Лийметс. - М. : Знание, 1975. - 162 с. 7. Табачник Д. Р. Розвиток початкової загальної освіти $\epsilon$ одним із найважливіших пріоритетів діяльності / Д. Табачник // Початкова школа. - 2013. - № 1. - С. 2 5. 8. Харламов И. Ф. Педагогика / И. Ф. Харламов. - М. : Гардарики, 1999. - 520 с. 9. Шевчук Л. М. Форми й види групової роботи учнів / Л. М. Шевчук // Педагогіка і психологія. - 2011 - №2 (71). - С. 54-62. 